\title{
Quantum-chemical calculations of transitional states thermodynamic parameters of tautomers of initial $N, N$ '-disubstituted thiourea derivative during the cyclization reaction in the conditions of different solvents application
}

\author{
L. O. Perekhoda ${ }^{1}$, H. O. Yeromina ${ }^{1}$, Z. G. Ieromina ${ }^{1}$, N. V. Sheykina ${ }^{1}$, I. V. Krasovskyi ${ }^{1}$, \\ M. V. Krasovska ${ }^{2}$, I. P. Storozhenko ${ }^{1}$ \\ ${ }^{1}$ National University of Pharmacy \\ 53, Pushkinska Str., Kharkiv, Ukraine, 61002 \\ ${ }^{2}$ SSI "Institute for Single Crystals", NAS of Ukraine \\ 60, Nauky ave., Kharkiv, Ukraine, 61001 \\ e-mail:sheykina@ukr.net
}

\begin{abstract}
Aim. Theoretical substantiation of directions of the cyclization reaction in different solvents by means of quantum-chemical calculations of thermodynamic parameters of three tautomers of the initial N-ethyl-N'-[4-(6,7,8,9-tetrahydro-5H-[1,2,4]triazol[4,3-a]azepin-3-yl) phenyl]thiourea. Methods. Quantum-chemical calculations of relative energies, interconversion barriers, structural and thermodynamic parameters of tautomers of thiourea in dioxane, ethanol, dimethylformamide (DMFA) and tetrachlormethane were performed on the basis of the density functional theory applying the GAUSSIAN 09W software. The influence of the solvent was taken into account within the framework of the continuum polarized model. Results. In all the solvents under study, the cyclization reaction must proceed in one direction to form the N-ethyl-4-phenyl-N'-[4-(6,7,8,9-tetrahydro-5H-[1,2,4]triazol[4,3a]azepin-3-yl) phenyl]-1,3-thiazole-2(3H)-imine. The smallest barrier of initial thiourea tautomers interconversion was observed in the presence of dioxane as a solvent; this fact indicated the advantage of synthesis conducting in this solvent precisely in comparison to ethanol, water, tetrachlormethane and DMFA. Conclusions. Dioxane is the most suitable solvent for cyclization.
\end{abstract}

Ke y w o r d s: $5 \mathrm{H}-[1,2,4]$ triazol[4,3-a]azepines, cyclization, quantum-chemical calculations, activating energy, relative energy, saddle point (transitional state).

\section{Introduction}

Modern quantum-chemical methods gain and reactivity of organic compounds [1-3]. widespread acceptance in the study of structure One of the most important and interesting

(C) 2019 L. O. Perekhoda et al.; Published by the Institute of Molecular Biology and Genetics, NAS of Ukraine on behalf of Biopolymers and Cell. This is an Open Access article distributed under the terms of the Creative Commons Attribution License (http://creativecommons.org/licenses/by/4.0/), which permits unrestricted reuse, distribution, and reproduction in any medium, provided the original work is properly cited 
directions of their application is related to the study of chemical reactions paths. The results of the theoretical research allow complementation and deepening of the interpretation of the experiment, and in some cases even its improvement by using in the synthesis more suitable solvent.

It was proved earlier that the molecule of $N$-ethyl- $N^{\prime}$-[4-(6,7,8,9-tetrahydro- $5 \mathrm{H}$ $[1,2,4]$ triazol[4,3-a]azepin-3-yl)phenyl]thiourea has a higher analgesic activity than ketorolac, the most common analogue with the same pharmacological action [4].

Investigation of the $N$-ethyl- $N$ '-[4- $(6,7,8,9-$ tetrahydro- $5 H$ - $[1,2,4]$ triazol[4,3-a]azepin-3yl)phenyl]thiourea isolated molecule in different media is also required for studying the environment influence on its structure, solving the problems of hydration, interaction with proteins, etc.; in particular, analgesic activity due to inhibition of cyclooxygenase activity (COX-1 and COX-2) and prostaglandins synthesis blockage.

Our earlier research on the regioselectivity of cyclization reaction of $N$-ethyl- $N$ '-[4(6,7,8,9-tetrahydro-5H-[1,2,4]triazol[4,3-a] azepin-3-yl)phenyl] thiourea with $\alpha$-bromoketone in water and without solvent showed availability of application of quantumchemical calculations of the electronic structure, geometry and thermodynamic parameters of initial thiourea tautomers, which was confirmed by the results of physical and chemical studies of the synthesized product of cyclization [5].

The next step of this research was theoretical substantiation of the direction of the cyclization reaction in conditions of synthesis in different solvents. The selection of the optimal solvent for synthesis was carried out by calculating the thermodynamic parameters of the initial tautomers in the medium of ethanol, DMFA, dioxane and tetrachlormethane using the licensed software product Gaussian W09, Revision A.02. This program provides an opportunity to calculate the physical and chemical parameters of the raw materials for synthesis both in gas phase and condensed state with high precision and reliability [6].

The most popular DFT functionals and PCM models nowadays allows the solution of such tasks as calculation and comparison of structural, electronic characteristics, relative energy of tautomers that theoretically may exist and energy barriers to their transformation; definition of the structure of intermediate products of the reaction.

It is known that during choosing a method of calculation the nature of a particular problem should be taken into account since various methods used in quantum-chemical calculations have specific disadvantages that limit their application.

The methods of the density functional theory of B3LYP and M06-2X were chosen as the main calculation methods for our purpose - the selection of solvent with the most favorable parameters for synthesis; the basis set 6-31+ $G(d)$ and the continuum model PCM implemented in Gaussian W09, Revision A.02 were used. [7].These models are widely applied in the practice of solvation effects in heterocyclic compounds.

The popularity of the hybrid method Beck3Lee-Yang-Parr (B3LYP) is due to the fact that its applying allows description of the processes that include a wide range of chemical transformations. However, a significant disad- 
vantage of this method is that it does not take into account the dispersion interactions, which results in the underestimation of the activation energy value and inaccuracies in describing the processes where the essential role is played by the effects associated with Van der Waals interaction [1]. Thus, more accurate and at the same time accessible methods are necessary for describing complex chemical processes. For the calculations of thermochemical kinetics, weak intermolecular interaction and excited states, we proposed a complex of metahybrid functionals M06 [7], which is based on an improved generalized gradient approximation (GGA). The M06-2X method was specially designed for kinetic studies, it has $54 \%$ of $\mathrm{HF}$ exchange function and is most effective in solving our problem.

The frequencies of harmonic oscillations were calculated for the determination of stationary points (minima with all positive frequencies; the transition state is corresponded to the presence of one imaginary frequency).

An analysis of the solvation effects, that we have carried out earlier for tautomers of $N$, $N$ '-disubstituted thiourea in the frame of the PCM model with bases of medium size (B3LYP / 6-31 + G (d) and M06-2X / 6-31 + $G(d)$ ), found a fairly strong influence of the solvent on the position of tautomeric equilibrium in the studied compounds [5]. According to the research results, the additional optimization of tautomers geometry in solutions with the application of larger bases leads only to small changes in the activation energy and is not necessary. The estimated and experimental data are consistently identical, and this fact allows us to rely on the correctness of predic- tions of the influence of solvents on the thermodynamic characteristics of the compounds studied.

\section{Materials and Methods}

$\mathrm{N}$-ethyl- $\mathrm{N}^{\prime}$-[4-(6,7,8,9-tetrahydro-5H$[1,2,4]$ triazol[4,3- $a]$ azepin-3-yl)phenyl] thiourea $I$ has two mobile hydrogen atoms in positions $\boldsymbol{N}$ and $\boldsymbol{N}$, so the molecule can exist in different tautomeric forms $\boldsymbol{I} \boldsymbol{A}$ and $\boldsymbol{I} \boldsymbol{B}$ as it is shown in the Scheme 1.

During the interaction of $N, N^{\prime}$-disubstituted thiourea $\boldsymbol{I}$ with 2-bromo-1-phenylethanone $\boldsymbol{I I}$ $[4,8]$ by boiling in dioxane according to data of ${ }^{1} \mathrm{H}$ NMR spectroscopy, one product is formed. For this product two structures can be assumed: hydrobromide 3-ethyl-4-phenyl$N$-[4-(6,7,8,9-tetrahydro-5 $H$-[1,2,4]triazol[4,3a] azepin-3-yl)phenyl]-1,3-thiazol-2(3H)-imine IV $\boldsymbol{A}$ and hydrobromide 3-[4-(6,7,8,9-tetrahydro-5H-[1,2,4]triazol[4,3-a]azepin-3-yl) phenyl]-4-phenyl- $N$-ethyl-1,3-thiazol-2(3H)imine $\boldsymbol{I V} \boldsymbol{B}$.

The formation of the 2-R-imino-1,3thiazoline derivative $\boldsymbol{I V} \boldsymbol{A}$ or $\boldsymbol{I V} \boldsymbol{B}$, credibly occurs through the formation of acyclic intermediate III-III $\boldsymbol{A}$ or III-III B with 2-bromo1-phenylethanone $\boldsymbol{I I}$ followed by intramolecular cyclization, accompanied by loss of water molecule.

In order to establish the tautomer structure, the formation of which is most probable, we conducted quantum-chemical calculations using the software Gaussian W09.

Using the meta-hybrid method M06-2X applying a basis functions set 6-31 + G (d), the local minima and transition states (saddle points) of $\boldsymbol{I}, \boldsymbol{I} \boldsymbol{A}$ and $\boldsymbol{I B}$ molecules in a medium of water, dioxane, ethanol, DMFA, tetrachlor- 


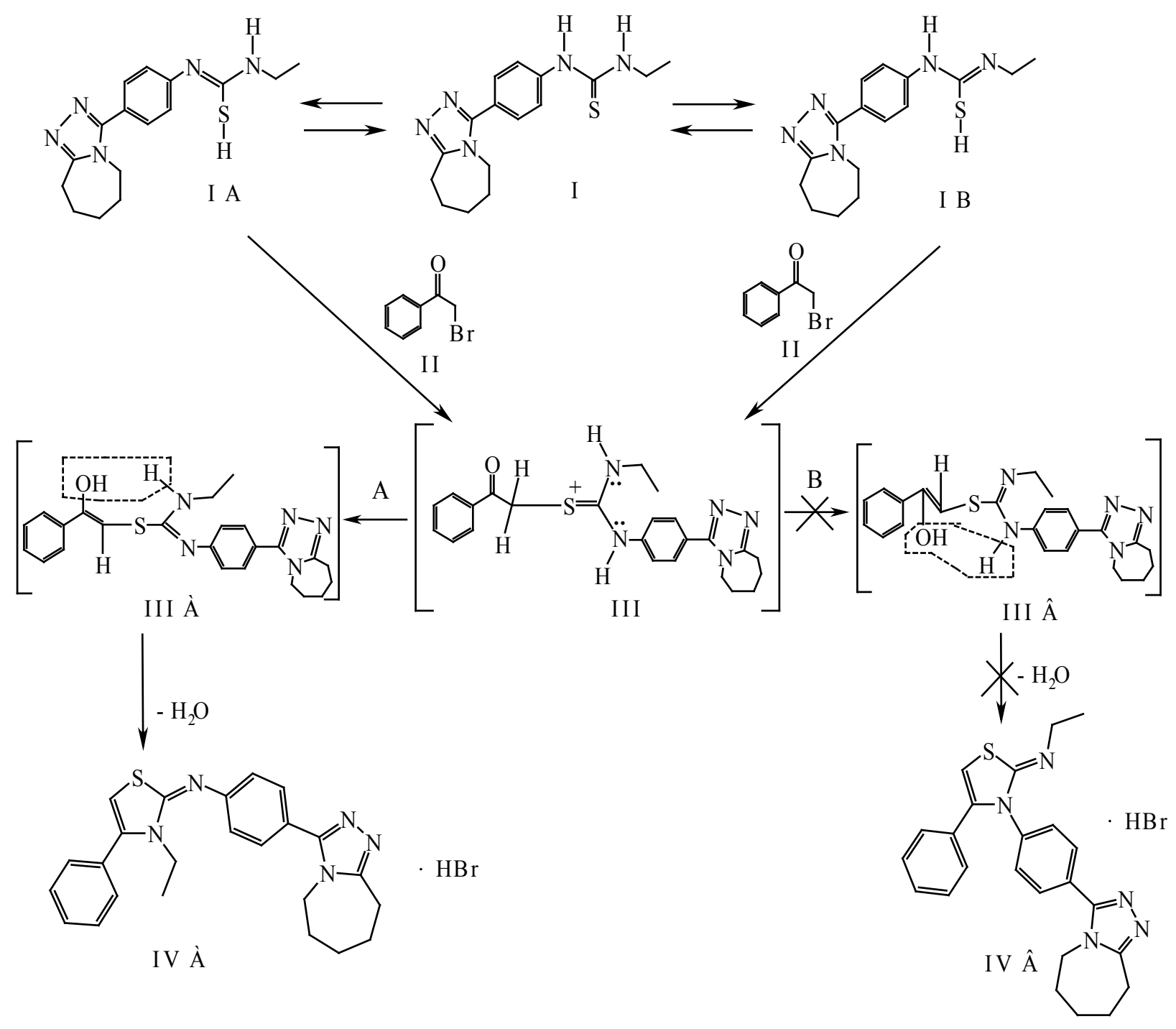

Scheme 1

methane were investigated. For the spatial structures obtained, the thermodynamic parameters were calculated as well as the relative energies and activation energies of tautomeric transformations for the transition states $\boldsymbol{I} \leftrightarrow \boldsymbol{I} \boldsymbol{A}$ and $\boldsymbol{I} \leftrightarrow \boldsymbol{I} \boldsymbol{B}$. The calculations were carried out in the framework of the traditional B3LYP method.

\section{Results and Discussion}

The presence of only one set of Hydrogen protons signals in the ${ }^{1} \mathrm{H}$ NMR spectrum of the cyclized product synthesized testifies to the formation of one of the possible structures $\boldsymbol{I V} \boldsymbol{A}$ or $\boldsymbol{I V} \boldsymbol{B}$ [5].

According to the results of quantum-chemical calculations obtained by two methods - B3LYP- 
Thermodynamic parameters of tautomers of initial $N, N$ '-disubstituted thiourea derivative during the cyclization reaction

Relative total energy of tautomers by the method B3LYP-6-31+g(d)

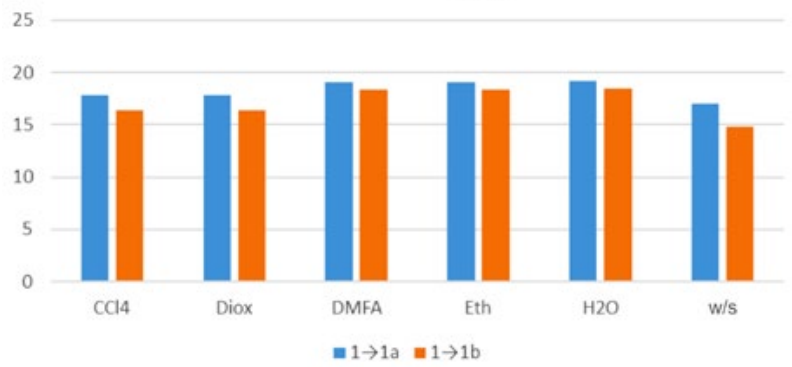

Relative total energy of tautomers by the method M06-2X-6-31+g(d)

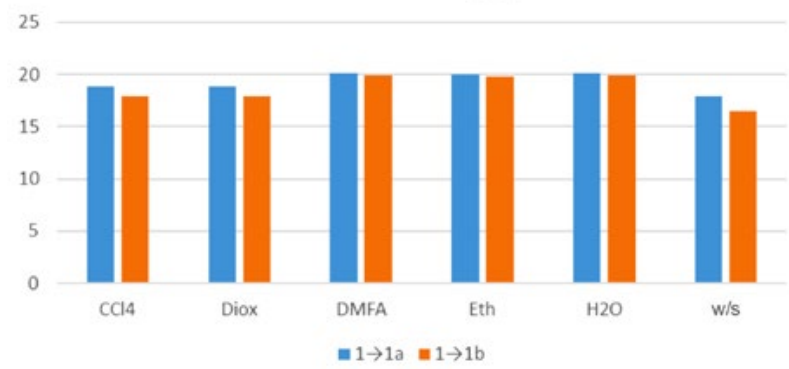

Fig. 1. Comparison of the relative energies of the corresponding tautomers in various solvents calculated by the methods B3LYP-6-31+g(d) and M06-2X-6-31+g(d)

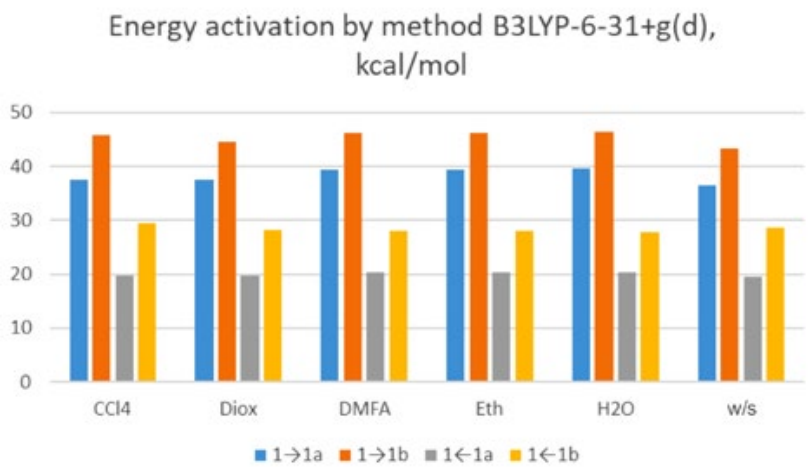

\section{Energy activation by method M06-2X- $6-31+\mathrm{g}(\mathrm{d}), \mathrm{kcal} / \mathrm{mol}$}

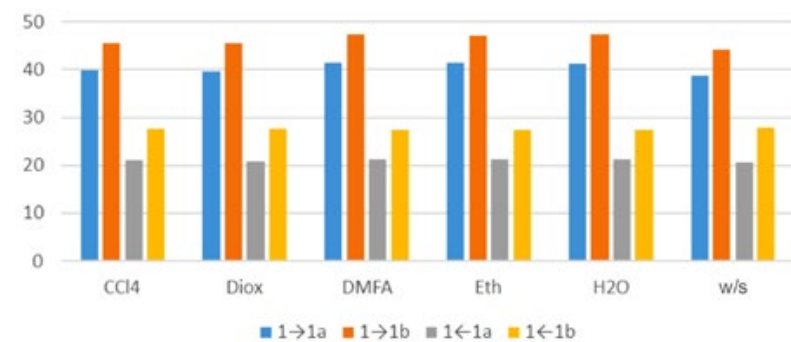

Fig. 2. Comparison of activation energies of corresponding tautomers in various solvents, calculated by methods B3LYP-6-31+g(d) and M06-2X-6-31+g(d)

$6-31+g(d)$ and M06-2X-6-31+g(d) - in water and without solvent (w/s) [5], dioxane, ethanol, DMFA and tetrachlormethane (Fig. 1-2, tab. $1-4), \boldsymbol{I} \boldsymbol{A}$ is more stable isomer that is endothermically conducive to the $\boldsymbol{I} \boldsymbol{V} \boldsymbol{A}$ [formation]. The results of X-ray structure analysis finally confirmed the formation of the structure $\boldsymbol{I V} \boldsymbol{A}$ [5].

The theoretical results of calculations of thermodynamic parameters of $N$-ethyl- $N$ '[4-(6,7,8,9-tetrahydro-5H-[1,2,4]triazol[4,3-a] azepin-3-yl)phenyl]thiourea $I$ tautomers were obtained by the methods B3LYP and M06-2X after optimization of the molecules spatial structure in the medium of dioxane, ethanol,
DMFA and tetrachlormethane. The calculated parameters - relative energy, activation energy, free energy of Gibbs and enthalpy - are given

Table 1. Relative energy calculated by the methods B3LYP-6-31+g(d) and M06-2X-6-31+g(d), $\mathrm{kcal} / \mathrm{mol}$

\begin{tabular}{l|c|c|c|c}
\hline \multicolumn{1}{c|}{ Method } & \multicolumn{2}{c|}{ B3LYP-6-31+g(d) } & \multicolumn{2}{c}{ M06-2X-6-31+g(d) } \\
\cline { 1 - 4 } \multicolumn{1}{c|}{ Mransient states } & \multirow{2}{*}{$\boldsymbol{I} \rightarrow \boldsymbol{I} \boldsymbol{A}$} & $\boldsymbol{I} \rightarrow \boldsymbol{I} \boldsymbol{B}$ & $\boldsymbol{I} \rightarrow \boldsymbol{I} \boldsymbol{A}$ & $\boldsymbol{I} \rightarrow \boldsymbol{I} \boldsymbol{B}$ \\
\cline { 1 - 1 } $\mathrm{CCl}_{4}$ & 17.857 & 16.363 & 18.829 & 17.988 \\
\hline Diox & 17.849 & 16.349 & 18.821 & 17.975 \\
\hline DMFA & 19.094 & 18.390 & 20.077 & 19.861 \\
\hline Eth & 19.038 & 18.309 & 20.023 & 19.788 \\
\hline $\mathrm{H}_{2} \mathrm{O}$ & 19.154 & 18.476 & 20.136 & 19.940 \\
\hline $\mathrm{w} / \mathrm{s}$ & 17.017 & 14.806 & 17.959 & 16.505 \\
\hline
\end{tabular}


L. O. Perekhoda, H. O. Yeromina, Z. G. Ieromina et al.

Table 2. The activation energy of tautomers $I A$ and $I B$, calculated by the methods B3LYP-6-31+g(d) and M06-2X-6-31+g(d), $\mathrm{kcal} / \mathrm{mol}$

\begin{tabular}{|c|c|c|c|c|c|c|c|c|}
\hline \multirow{3}{*}{$\begin{array}{c}\text { Method } \\
\text { Transient states } \\
\text { Medium } \\
\end{array}$} & \multicolumn{4}{|c|}{ B3LYP-6-31+g(d) } & \multicolumn{4}{|c|}{ M06-2X-6-31+g(d) } \\
\hline & $I \rightarrow I A$ & $I \rightarrow I B$ & $I \leftarrow I A$ & $I \leftarrow I B$ & $I \rightarrow I A$ & $I \rightarrow I B$ & $I \leftarrow I A$ & $I \leftarrow I B$ \\
\hline & & & & & & & & \\
\hline $\mathrm{CCl}_{4}$ & 37.632 & 45.763 & 19.775 & 29.400 & 39.923 & 45.522 & 21.094 & 27.534 \\
\hline Diox & 37.621 & 44.531 & 19.772 & 28.182 & 39.739 & 45.511 & 20.918 & 27.536 \\
\hline DMFA & 39.350 & 46.284 & 20.256 & 27.894 & 41.456 & 47.288 & 21.379 & 27.426 \\
\hline Eth & 39.435 & 46.210 & 20.396 & 27.901 & 41.388 & 47.213 & 21.365 & 27.425 \\
\hline $\mathrm{H}_{2} \mathrm{O}$ & 39.555 & 46.363 & 20.401 & 27.887 & 41.315 & 47.368 & 21.179 & 27.428 \\
\hline $\mathrm{w} / \mathrm{s}$ & 36.483 & 43.350 & 19.466 & 28.543 & 38.651 & 44.272 & 20.692 & 27.767 \\
\hline
\end{tabular}

Table 3. The value of enthalpy tautomers $I, I A$ and $I B$, calculated by the methods B3LYP-6-31+g(d) and M06-2X-6-31+g(d), kcal/mol

\begin{tabular}{|c|c|c|c|c|}
\hline Method & \multicolumn{2}{|c|}{ B3LYP-6-31+g(d) } & \multicolumn{2}{|c|}{ M06-2X-6-31+g(d) } \\
\hline Transient states & \multirow{2}{*}{ I A } & \multirow{2}{*}{ I B } & \multirow{2}{*}{ I A } & \multirow{2}{*}{ I B } \\
\hline Medium & & & & \\
\hline $\mathrm{CCl} 4$ & 17.857 & 16.363 & 18.829 & 17.988 \\
\hline Diox & 17.849 & 16.349 & 18.821 & 17.975 \\
\hline DMFA & 19.094 & 18.390 & 20.077 & 19.861 \\
\hline Eth & 19.038 & 18.309 & 20.023 & 19.788 \\
\hline $\mathrm{H} 2 \mathrm{O}$ & 19.154 & 18.476 & 20.136 & 19.940 \\
\hline $\mathrm{w} / \mathrm{s}$ & 17.017 & 14.806 & 17.959 & 16.505 \\
\hline
\end{tabular}

Table 4. The value of free energy of Gibbs tautomers $I, I A$ and $I B$, calculated by the methods B3LYP-6-31+g(d) and M06-2X-6-31+g(d), $\mathrm{kcal} / \mathrm{mol}$

\begin{tabular}{l|c|c|c|c}
\hline \multicolumn{1}{c|}{ Method } & \multicolumn{2}{|c|}{ B3LYP-6-31+g(d) } & \multicolumn{2}{c}{ M06-2X-6-31+g(d) } \\
\cline { 1 - 4 } \multicolumn{1}{c|}{ Transient states } & I A & I B & I A & I B \\
\cline { 1 - 4 } Medium & & & & \\
\hline CC14 & 15.194 & 13.823 & 16.340 & 15.539 \\
\hline Diox & 15.187 & 13.809 & 16.336 & 15.527 \\
\hline DMFA & 16.312 & 15.709 & 17.699 & 17.451 \\
\hline Eth & 16.264 & 15.620 & 17.644 & 17.384 \\
\hline w/s & 16.366 & 15.812 & 17.746 & 17.522 \\
\hline
\end{tabular}

in tab. 1-4 and in fig. 1-2. All energy parameters are calculated in conditions $T=298.15 \mathrm{~K}$ and $P=1$ ath.
As can be seen from the data in Tab. 1-4, in most cases for energy and energy barriers there is a reliable $(1-2 \mathrm{kcal} / \mathrm{mol})$ coincidence of the calculations results obtained by the methods M06-2X and B3LYP. The calculated data and the obtained data of the physicalchemical researches of the interaction product more accurately coincide with the application of the method M06-2X.

Thus, using the methods of B3LYP and M06-2X of the density functional theory, the main directions and transition states of the reaction that determine the formation of hydrobromide 3-ethyl-4-phenyl-N-[4-(6,7,8,9tetrahydro-5H-[1,2,4]triazol[4,3-a]azepin-3-yl) phenyl]-1,3-thiazol-2(3H)-imine $\boldsymbol{I V} \boldsymbol{A}$ were found regardless of the test solvents choice.

As can be seen from Table 1, a transition state $\boldsymbol{I} \leftrightarrow \boldsymbol{I} \boldsymbol{A}$ in dioxane has the lowest values of activation energy. The graphical representation of the 3D isomers of structure $\boldsymbol{I}$ and the activation energy of tautomeric transformations for the transition states $\boldsymbol{I} \boldsymbol{A} \leftrightarrow \boldsymbol{I} \leftrightarrow \boldsymbol{I} \boldsymbol{B}$ in dioxane for both methods is shown in Fig. 3

Despite the fact that the values of the thermodynamic potentials for transition states in dioxane and tetrachlormethane are the same, the activation energy and the relative energy 


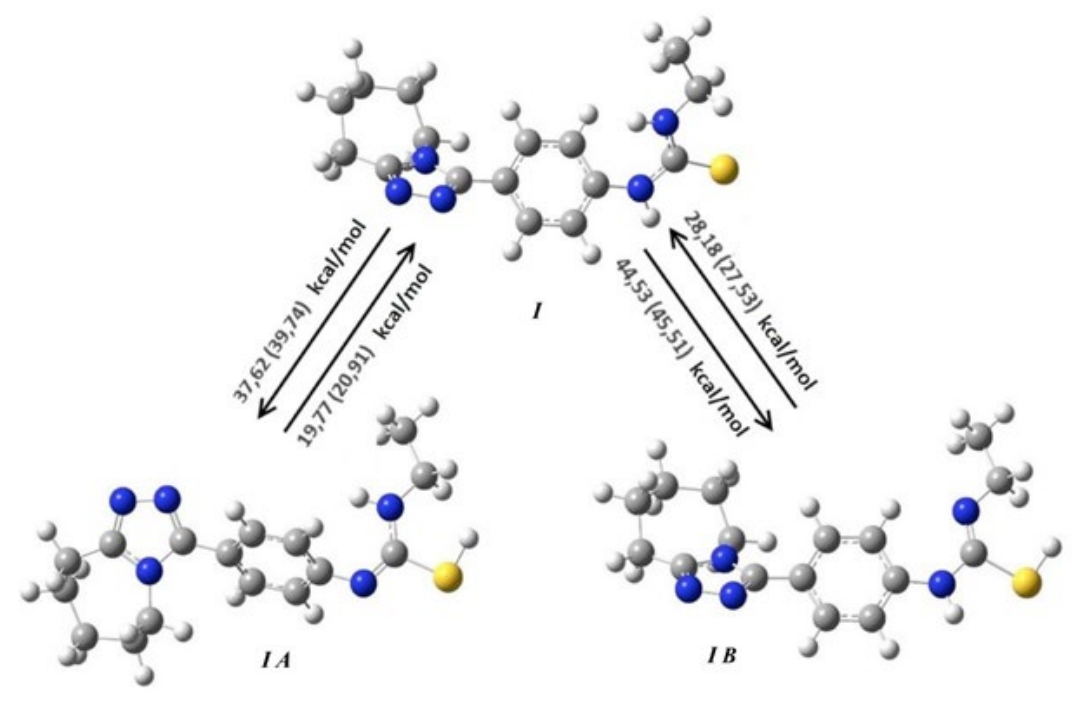

Fig. 3. Graphical view of the 3D isomers of structure $\boldsymbol{I}$ and activation energies of tautomeric transformations for the transition states $\boldsymbol{I} \boldsymbol{A} \leftrightarrow \boldsymbol{I} \leftrightarrow \boldsymbol{I} \boldsymbol{B}$ in dioxane by the methods B3LYP-6-31 + g (d) and M06$2 \mathrm{X}-6-31+\mathrm{g}(\mathrm{d})$ in brackets of the transient state $\boldsymbol{I} \leftrightarrow \boldsymbol{I} \boldsymbol{A}$ in dioxane are the lowest. Compared with the values of these parameters of the transition states of compound $\boldsymbol{I}$ in dioxane, the corresponding parameters for transitional states $\boldsymbol{I} \leftrightarrow \boldsymbol{I} \boldsymbol{A}$ and $\boldsymbol{I} \leftrightarrow \boldsymbol{I} \boldsymbol{B}$ in the environment of other solvents (ethanol, DMFA and tetrachlormethane) have considerably higher values (Table 1-4), and hence, the synthesis in these solvents will be slower and will require additional conditions.

Taking into account these data, we can conclude that according to the two methods of quantum-chemical calculations, the reaction pathway by $\boldsymbol{A}$, which indicates the formation of hydrobromide 3-ethyl-4-phenyl- $N$-[4(6,7,8,9-tetrahydro-5H-[1,2,4]triazol[4,3-a] azepin-3-yl)phenyl]-1,3-thiazol-2(3H)-imine IV $\boldsymbol{A}$, is the most probable, and the synthesis of the substance is the most energy-efficient in the environment of dioxane.

\section{Conclusions}

The obtained results of quantum-chemical calculations indicate that in all the solvents studied (dioxane, ethanol, DMFA, tetrachlormethane, water) the cyclization reaction theoretically should lead to the formation of hydrobromide 3-ethyl-4-phenyl- $N$-[4-(6,7,8,9-tetrahydro$5 H$-[1,2,4]triazol[4,3-a]azepin-3-yl)phenyl]-1,3thiazol-2(3H)-imine. It was theoretically proved that the most appropriate solvent for the synthesis is dioxane. It is proposed to apply in the further research the method of quantum-chemical calculations M06-2X as more reliable.

\section{REFERENCES}

1. Davtyan AH, Asatryan RS, Arsentev SD, Mantashyan $A A$. The study of potential energy surface of oxygen atom interaction with ethylene. Chem $J$ Armenia. 2015; 68(3):358-66.

2. Plutecka A, Rychlewska U, Prusinowska N, Gawron'ski, J Gawron'ski. Solid solution of two diastereomers of $[3 \mathrm{a}(\mathrm{R}, \mathrm{S}), 7 \mathrm{a}(\mathrm{R}, \mathrm{S})]-3-\left[\left(1^{\prime} \mathrm{R}\right)-1\right.$ phenylethyl]perhydro-1,3-benzothiazol-2-iminium chloride. Acta Cryst. 2010; B66:678-86.

3. Umape PG, Patil VS, Padalkar VS, Phatangare KR, Gupta VD, Thate AB, Sekar N. Synthesis and characterization of novel yellow azo dyes from 2-morpholin-4-yl-1,3-thiazol-4(5H)-one and study of their 
azo-hydrazone tautomerism. Dyes Pigm. 2013; 99(2):291-8.

4. Demchenko SA, Yeromina HO, Perekhoda L O, Yadlovsky OJe, Bobkova LS, Demchenko AM. (3-ethyl-4-phenyl-3H-thiazole-2-ylidene)-[4$(6,7,8,9$-tetrahydro-5H-[1,2,4]triazolo[4,3-a]azepin3-yl)phenyl]amine hydrobromide, which possesses analgesic activity: pat. 111015 Ukraine. N u 2016 04704; appl. 26.04.2016; publ. 25.10.2016, Bull. N20.

5. Perekhoda LO, Yeromina HO, Storozhenko IP, Sheykina NV, Krasovskyi IV, Krasovska MV, Demchenko $S A$. The presentation of regioselectivity of 1 -ethyl-3-[4-(6,7,8,9-tetrahydro-5H-[1,2,4] triazol[4,3-a]azepin-3-yl)phenyl]thiourea cyclization with $\alpha$-bromoketone. $\check{Z}$ org farm him. 2017; 15:1(57):58-63.

6. Gaussian 09, Revision A.02. MJ Frisch, GW Trucks, HB Schlegel, GE Scuseria, MA Robb, JR Cheeseman, G Scalmani, V Barone, GA Petersson, $\mathrm{H} \mathrm{Na-}$ katsuji, X Li, M Caricato, A Marenich, J Bloino, BG Janesko, R Gom-perts, B Mennucci, HP Hratchian, JV Ortiz, AF Izmaylov, JL Sonnenberg, D Williams-Young, F Ding, F Lippari-ni, F Egidi, J Goings, B Peng, A Petrone, $T$ Henderson, D Ranasinghe, VG Zakrzewski, J Gao, N Rega, G Zheng, W Liang, M Hada, M Ehara, K Toyota, R Fukuda, $J$ Hasegawa, M Ishida, T Nakajima, Y Honda, O Kitao, H Na-kai, T Vreven, K Throssell, JA Montgomery, JrJE Peralta, F Ogliaro, M Bearpark, JJ Heyd, E Brothers, K N Kudin, VN Staroverov, $T$ Keith, R Kobayashi, J Normand, K Raghavachari, A Rendell, JC Burant, SS Iyengar, J Tomasi, M Cossi, JM Millam, M Klene, C Adamo, R Cammi, JW Ochterski, RL Martin, K Morokuma, O Farkas, JB Foresman, DJ Fox. Gaussian, Inc., Wallingford CT, 2016.

7. Zhao Ya, Truhlar DG. The M06 suite of density functionals for main group thermochemistry, thermochemical kinetics, noncovalent interactions, excited states, and transition elements: two new functionals and systematic testing of four M06-class functionals and 12 other functionals. Theor Chem Account. 2008; 120(1-3):215-41.
8. Demchenko SA, Yeromina HO, Bukhtiarova TA, Bobkova LS, Demchenko AM. Synthesis and analgesic properties of derivatives of (3-allyl-4- aryl-3Hthiazol-2-ylidene)-[4-(6,7,8,9-tetrahydro-5H-[1,2,4] triazol[4,3-a]azepin-3-yl)phenyl]amines. Farm Zn. 2017; 1:67-73.

Квантово-хімічні розрахунки термодинамічних параметрів перехідних станів таутомерів вихідної $N$, $N$ '-дизаміщеної тіосечовини у реакції циклізації при використанні різних розчинників

Л. О. Перехода, Г. О. Срьоміна, 3. Г. Срьоміна, Н. В. Шейкіна, І. В. Красовський, М. В. Красовська, І. П. Стороженко

Мета. Теоретичне обгрунтування напрямку проходження реакції циклізації в різних розчинниках за допомогою квантово-хімічних розрахунків термодинамічних параметрів двох таутомерів 1-етил-3-[4(6,7,8,9-тетрагідро-5H-[1,2,4]тріазоло[4,3- $]$ азепін-3іл)феніл]тіосечовини. Методи. Квантово-хімічні розрахунки відносних енергій, бар'єрів взаємоперетворення, структурних і термодинамічних параметрів таутомерів вихідної тіосечовини у середовищі діоксану, етанолу, ДМФА та тетрахлорметану були обчислені методами теорії функціонала густини з використанням програми GAUSSIAN 09W. Вплив розчинника враховували у рамках моделі континууму, що поляризується. Результати. Згідно одержаних результатів, в усіх досліджуваних розчинниках реакція циклізації має проходити в одному напрямку з утворенням гідроброміду 3-етил-4-феніл-N-[4-(6,7,8,9тетрагідро-5H-[1,2,4]тріазоло[4,3-a]азепін-3-іл) феніл]-1,3-тіазол-2(3H)-іміну. Найменший бар'єр взаємоперетворення таутомерів вихідної тіосечовини повинен спостерігатися при використанні як розчинника діоксану, що свідчить про перевагу проведення синтезу саме у цьому розчиннику порівняно з етанолом, водою, тетрахлорметаном та ДМФА. Висновки. Теоретично обгрунтовано, що для проведення синтезу найбільш доцільним $є$ використання як розчинника діоксану. 


\section{Квантово-химические расчеты термодинамических параметров переходных состояний таутомеров исходной $N, N$ '- дизамещенной тиомочевины в реакции циклизации при использовании различных растворителей}

Л. А. Перехода, А. А. Еремина, 3. Г. Еремина, Н. В. Шейкина, И. В. Красовский,

М. В. Красовская, И. П. Стороженко

Цель. Теоретическое обоснование направления прохождения реакции циклизации в различных растворителях с помощью квантово-химических расчетов тер-

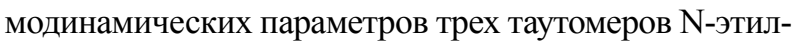
N'-[4-(6,7,8,9-тетрагидро-5Н-[1,2,4]триазоло[4,3-a] азепин-3-ил)фенил]тиомочевины. Методы. Кванто-вохимические расчеты относительных энергий, барьеров взаимопревращения, структурных и термодинамических параметров таутомеров исходной тиомочевины в среде диоксана, этанола, ДМФА и тетрахлорметана были вычислены методами теории функционала плотности с использованием программы GAUSSIAN 09W. Влияние растворителя учитывали в рамках модели поляризуемого континуума. Результаты. Согласно полученных результатов, во всех исследуемых растворителях реакция циклизации должна проходить в одном направлении с образованием гидробромида 3-этил-4-фенил-N-[4-(6,7,8,9-тетрагидро-5Н-[1,2,4] триазоло[4,3-а]азепин-3-ил)фенил]-1,3-тиазол-2(3Н)-имина. Наименьший барьер взаимопревращения таутомеров исходной тиомочевины должен наблюдаться при использовании в качестве растворителя диоксана, что свидетельствует о преимуществе проведения синтеза именно в этом растворителе по сравнению с этанолом, водой, тетрахлорметаном и ДМФА. Выводы. Теоретически обосновано, что наиболее подходящим растворителем для проведения циклизации является диоксан.

Received 22.05.2018 